Article

\title{
Distribution of Canthon rutilans rutilans and Canthon rutilans cyanescens Along Spatio-Temporal and Temperature Gradients
}

\author{
Maristela Carpintero Hensen ${ }^{1, *} \mathbb{0}$, Malva Isabel Medina Hernández ${ }^{1}$, Pedro Giovâni da Silva ${ }^{1}$, \\ Valentina Amore ${ }^{1}$ D and Jorge M. Lobo ${ }^{2}$ \\ 1 Programa de Pós-Graduação em Ecologia, Universidade Federal de Santa Catarina, Florianópolis 88040-900, \\ Santa Catarina, Brazil; malva.medina@ufsc.br (M.I.M.H.); pedrogiovanidasilva@yahoo.com.br (P.G.d.S.); \\ valenamore@gmail.com (V.A.) \\ 2 Department of Biogeography and Global Change, Museo Nacional de Ciencias Naturales, 28006 Madrid, \\ Spain; mcnj117@mncn.csic.es \\ * Correspondence: maristelacarpintero@gmail.com
}

Received: 17 July 2018; Accepted: 18 September 2018; Published: 21 September 2018

check for updates

\begin{abstract}
Subspecies is a debated taxonomic rank that, in some cases, could indicate that a speciation process is taking place. Studying the degree of co-occurrence among subspecies along environmental gradients may help to determine its taxonomic status. In this study, we explore the distribution of two subspecies of Canthon rutilans along spatio-temporal and temperature gradients in the Atlantic Forest of southern Brazil in order to reinforce their current subspecies status or to support their consideration as two different species. A yearly survey conducted along an elevational transect (from $250 \mathrm{~m}$ to $1630 \mathrm{~m}$ ) shows that there is no spatio-temporal overlap between the two taxa. We collected 899 individuals of Canthon rutilans cyanescens and 29 individuals of Canthon rutilans rutilans. C. rutilans cyanescens can be found at $250 \mathrm{~m}$ (all year except in June), $430 \mathrm{~m}$ (August to April), and $840 \mathrm{~m}$ (September to April) in elevation, and when the air temperature oscillates from $15.3^{\circ} \mathrm{C}$ to $24.0^{\circ} \mathrm{C}$. C. rutilans rutilans can be found at $1360 \mathrm{~m}$ (October to February), $1630 \mathrm{~m}$ (January) in elevation, and when the air temperature oscillates from $14.4{ }^{\circ} \mathrm{C}$ to $18.6{ }^{\circ} \mathrm{C}$. Furthermore, local temperature data taken during the survey indicates that both subspecies also have a limited overlap in their thermal response curves. All these results suggest that these two taxa could be considered as two different species with dissimilar physiological and ecological requirements probably as a consequence of temperature-mediated divergent adaptation. Further molecular data can confirm or reject this supposition in the near future.
\end{abstract}

Keywords: speciation; dung beetles; Canthon rutilans; elevation; gradient; temperature; spatio-temporal distribution

\section{Introduction}

The lack of spatial and temporal co-occurrence in taxonomically related taxa, as well as their differential distribution across environmental gradients, has traditionally been considered key evidence, which identifies specific characteristics of related taxa with a recent common ancestor [1-4]. Thus, in order to establish the species status of morphologically similar taxa, it is important to understand the environmental or ecological factors that allow or hinder their coexistence. Although the mechanisms of speciation are considered complex, varied, and interlinked, isolation and lack of hybridization seem to be a necessary requisite since these generate divergent natural selection forces on different environmental conditions [5]. Thus, the role played by different potential isolating barriers on species pairs recently achieving their species status may shed light on possible speciation processes. 
The elevational gradient is a limiting factor for the spatial and temporal distribution of most organisms exposed to climatic variations (e.g., temperature, humidity, atmospheric pressure, insolation, wind, and precipitation) [6,7]. Tropical insects are highly affected by temperature due to their general narrow physiological tolerances [8] and this limitation may restrict their realized and potential distributions. As consequence, the environmental temperature may be a divergent selection pressure promoting speciation because populations living at different environmental temperatures may become isolated $[9,10]$.

Subspecies is a controversial taxonomical rank, subordinate to species, not always representative of distinct phylogenetic lineages [11] in which individuals do not have reproductive isolation, even though they have some different characteristics [12]. In some cases, subspecies are identifiable taxa experiencing a process of incipient speciation. Consequently, the degree of co-occurrence between related subspecies across environmental gradients would support or refute their taxonomic status. Data on the seasonal and spatial distribution of two subspecies of dung beetles are used in this study to provide additional evidence on their possible taxonomic status. Since environmental temperature may affect the distribution and abundance of ectothermic groups, such as insects, due to its influence on metabolic functions and development or growth rates [13], we also used local temperature measurements to examine the degree of segregation between these two subspecies.

Canthon (Francmonrosia) rutilans Castelnau, 1840 is a Neotropical dung beetle species (Coleoptera: Scarabaeidae: Scarabaeinae) whose distribution extends from the province of Misiones in Argentina to the states of Mato Grosso do Sul, São Paulo, Paraná, Santa Catarina, and Rio Grande do Sul in Brazil, and lastly to Uruguay [14]. The climate in this large region corresponds to group C in Köppen climate classification (including $\mathrm{Cf}$ and $\mathrm{Cw}$ ), that is, midlatitude climate, in which the average temperature of the coldest month is between -3 and $18{ }^{\circ} \mathrm{C}$, and the warmest above $10^{\circ} \mathrm{C}$ [15]. Like other species of the genus Canthon, they are diurnal, and larvae and adults feed mainly on faeces or carrion [16]. Adults carry food in the form of spherical balls in order to save food resources, as well as to make nesting balls where larvae develop [17]. Due to this behavior, the dung beetles are very active in the ecosystem service of organic matter removal [18].

This species is separated into two subspecies: The originally described red colored (on the back) Canthon rutilans rutilans Castelnau, 1840 and the blue colored Canthon rutilans cyanescens Harold, 1868. Color polymorphism in Scarabaeinae species has been associated with the control of body temperature in response to environmental conditions $[19,20]$. Different coloration may be an evolutionary response linked to the thermal adaptation towards environmental conditions. Black dung beetles are usually nocturnal, whereas diurnal dung beetles show varied colors, thus, the diurnal species coloring may be important in sexual or natural selection [21]. Color in dung beetles is a property of the exoskeleton because it can reflect, disperse, and deflect light differentially depending on its wavelength. Beetles with darker colorations should be heated more at higher solar radiation levels, however, species of beetles with different colors may have a similar thermal response to visible light but not to infrared radiation. For example, Canthon rutilans rutilans (light red) compared to Homocopris sp. (deep black) have similar adjusted heating rates under simulated sun radiation [22].

Despite the different coloration in both subspecies, there is no knowledge of differential behavior. In regard to feeding habits, both C. rutilans cyanescens [23-25] and C. rutilans rutilans [26-30] have a preferentially coprophagous diet. However, revisions in the literature suggest that both subspecies do not seem to inhabit together, in the same locality: Canthon rutilans cyanescens is found in rainforest habitats with high temperatures located at elevations under $1000 \mathrm{~m}$ [23,31-39], while Canthon rutilans rutilans tends to be collected in grasslands or eucalyptus plantations in cold locations or in forests situated at more than $1000 \mathrm{~m}$ in elevation [26-29,40,41]. This divergence may be a result of a physiological adaptation to temperature for biogeographic reasons, which may have led to speciation.

Using data from a comprehensive survey conducted during a complete calendar year in several locations along an elevation gradient, this study aims to examine the degree of spatial and temporal segregation of these two subspecies in order to corroborate the suspected speciation. However, even if 
both subspecies are spatio-temporally segregated they could still share thermal niche preferences [42]; therefore, their degree of co-occurrence throughout a temperature gradient was also estimated. Accordingly, using local temperature information of each surveyed site and time, temperature response curves were also compared in order to estimate the degree of thermal niche overlap between the two taxa. The evidence found would then be used to reinforce their current subspecies status or to support their consideration as two different species.

\section{Material and Methods}

\subsection{Study Area}

Six sites were chosen along an elevation gradient in the Atlantic Forest of the state of Santa Catarina, southern Brazil. These sites were located along a transect extended northeast-southwest $\left(27^{\circ} 44^{\prime}\right.$ to $28^{\circ} 9^{\prime} \mathrm{S} ; 48^{\circ} 48^{\prime}$ to $\left.49^{\circ} 37^{\prime} \mathrm{W}\right)$ from 200 to $1600 \mathrm{~m}$ a.s.l. Two areas were located in the municipality of Santo Amaro da Imperatriz, one at $250 \mathrm{~m}$ and the second at $430 \mathrm{~m}$; one area in Rancho Queimado municipality at $840 \mathrm{~m}$; three areas in the municipality of Urubici, one area in RPPN-Reserva Leão da Montanha at 1060 m, and the other two areas in Parque Nacional de São Joaquim at $1360 \mathrm{~m}$ and $1630 \mathrm{~m}$. The study areas are classified into two climatic regions, Cfa and Cfb, according to Köppen climatic classification. Both regions present a uniform rainfall throughout the year and humid mesothermal climate. Cfb is located in elevations below $800 \mathrm{~m}$, with warm summer temperatures compared to Cfa (i.e., temperatures above $22^{\circ} \mathrm{C}$ ). Cfa is located above $800 \mathrm{~m}$ in elevation, with cooler summer temperatures (i.e., the temperature does not reach $22{ }^{\circ} \mathrm{C}$ ), and frost frequently occurs during colder months [15]. The vegetation in the study areas included dense ombrophilous forest, an evergreen forest whose canopy reaches $30 \mathrm{~m}$ and has dense shrub vegetation, consisting of ferns, bromeliads and palms, as well as a mixed ombrophilous forest characterized by the presence of Araucaria angustifolia, which appears at high elevations, above $800 \mathrm{~m}$ a.s.1. [43].

\subsection{Beetle Sampling}

Dung beetles were sampled monthly at each sampling site from June 2015 to June 2016 using traps that remained in the field for $48 \mathrm{~h}$. Along the elevation gradient, at each sampling site, we established five sampling points separated $100 \mathrm{~m}$ from each other. At each sampling point three different traps were placed, totaling 15 traps per sampling site, which included five traps that allowed both immigration and emigration (TIE), five traps that prevented emigration and were baited with human dung $\left(\mathrm{TE}_{\mathrm{D}}\right)$, and five traps that also prevented emigration, but were baited with rotting pork flesh $\left(\mathrm{TE}_{\mathrm{F}}\right)$. All the traps were plastic containers $(15 \mathrm{~cm}$ diameter and $20 \mathrm{~cm}$ depth) buried into the ground up to the rim and protected from rain by a plastic cover approximately $10 \mathrm{~cm}$ above the trap. TIE containers were filled with local soil and a piece of approximately $10 \mathrm{~g}$ of human dung was placed in the centre. $\mathrm{TE}_{\mathrm{D}}$ and $\mathrm{TE}_{\mathrm{F}}$ traps were similar, however, $200 \mathrm{~mL}$ of water and a few drops of detergent were added to each container to catch the attracted insects and avoid their escape. Human faeces or rotting flesh (also ca. $10 \mathrm{~g}$ ) were used to attract dung beetles (i.e., coprophagous and necrophagous species, respectively). The bait was wrapped in a thin cloth and tied to the central part of the plastic cap. The total number of individuals collected within the 15 traps placed at each site and period were considered as a sampling unit (the final number of used sampling units was 75 because on three occasions it was not possible to collect it).

All the Canthon rutilans individuals collected were identified and voucher specimens (dried and mounted on entomological pins) were deposited in institutional collections (Coleção Entomológica do Centro de Ciências Biológicas da Universidade Federal de Santa Catarina and Coleção Zoológica da Universidade Federal de Mato Grosso, Brazil). The taxonomist, Dr. Fernando Vaz-de-Mello, confirmed the species (Universidade Federal de Mato Grosso). The permission to collect dung beetles was issued by the Instituto Chico Mendes de Conservação da Biodiversidade (ICMBio/MMA, permit \#49486-1). 


\subsection{Temperature Measurements}

The local air temperature of each sampling site was measured every 15 min during the complete period of study using a datalogger (HOBO Pendant ${ }^{\circledR}$, Onset Computer Corporation, Bourne, MA, USA) placed on a tree trunk one meter from the ground.

\subsection{Data Analysis}

Generalized Linear Models (GLMs) were used to quantify the relevance of local temperature measurements on either the presence-absence of each species or the variation in their number of individuals. Separate models were run in order to compare the effect of temperature in delimiting both the occurrence of each species and the variation in abundance within the sampling units with positive occurrences. In the first case, we used a binomial error distribution linked to the set of predictor variables via a logit link function. In the second case, a Poisson distribution was assumed, and a logarithmic link function used. The significance of linear and quadratic functions was assessed to consider possible curvilinear relationships. Our aim with these models was simply to estimate the individual explanatory capacity of air temperature, and how this variability is measured as a change in deviance from a null model [44]. All these analyses were performed using StatSoft's STATISTICA v12.0 (StatSoft Inc., Tulsa, OK, USA).

A logistic fitting curve was used to visualize the relationship between air temperature experienced at each sampling unit during the sample time $(48 \mathrm{~h})$ and the relative frequency of both taxa. The adjusted curves are considered an estimation of the variation in the maximum attained abundance according to temperature. Taking into account the minimum $\left(5^{\circ} \mathrm{C}\right)$ and maximum $\left(25^{\circ} \mathrm{C}\right)$ mean temperatures registered during the surveys, the area under the adjusted curves of the two species was computed in order to measure the extent of their favorable thermal conditions. These calculations were completed using the software CurveExpert 1.4 (www.curveexpert.net). The value of the area under the curve for $C$. rutilans cyanescens $(A)$ and $C$. rutilans rutilans (B) were used to estimate the relative shared thermal range between the two subspecies $(C)$, calculated as: $\max (\mathrm{A}, \mathrm{B})-\mathrm{A}=\mathrm{B}-\mathrm{C}$; $\max (\mathrm{A}, \mathrm{B})-\mathrm{B}=$ $\mathrm{A}-\mathrm{C}$; and then $\mathrm{C}=\max (\mathrm{A}, \mathrm{B})-[(\mathrm{B}-\mathrm{C})+(\mathrm{A}-\mathrm{C})]$.

\section{Results}

\subsection{Spatial and Temporal Segregation}

A total of 899 individuals of $C$. rutilans cyanescens and 29 individuals of $C$. rutilans rutilans were collected. Most of the individuals of $C$. rutilans cyanescens $(\mathrm{N}=825,92 \%)$ were collected at the $250 \mathrm{~m}$ site throughout the year except in June, 52 individuals were sampled at the site located at $430 \mathrm{~m}$ from August to April, and 22 individuals at the $840 \mathrm{~m}$ site from September to April (Figure 1). In the case of C. rutilans rutilans most of the individuals $(\mathrm{N}=28,96 \%$ ) were collected at the site located at $1360 \mathrm{~m}$ during the hottest months of the year, from October to February; only one individual was sampled in January at the $1630 \mathrm{~m}$ site. Neither of these two subspecies occur in the site located at $1060 \mathrm{~m}$. Their absence emphasizes their spatial isolation as none of them seem to be able to maintain stable populations at intermediate elevations; the blue morphotype occurs at lower elevations (up to $860 \mathrm{~m}$ ) while the red one appears at the highest elevations (above $1360 \mathrm{~m}$ ). Consequently, and according to the obtained data, there is no spatio-temporal overlap between the two taxa (Figure 1). 


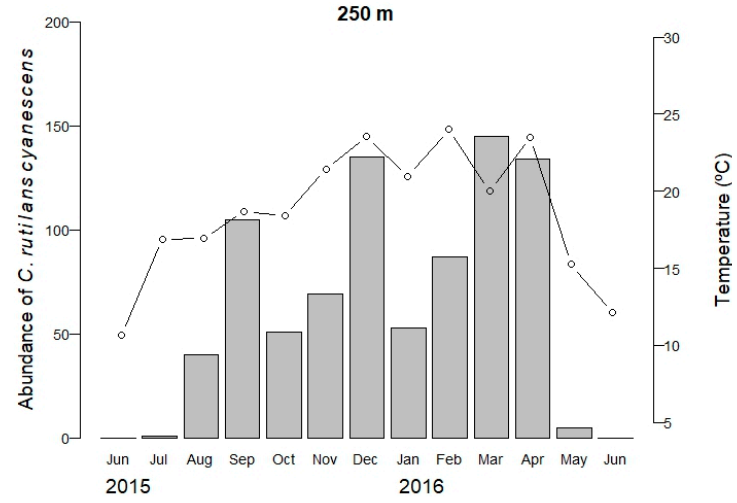

(A)

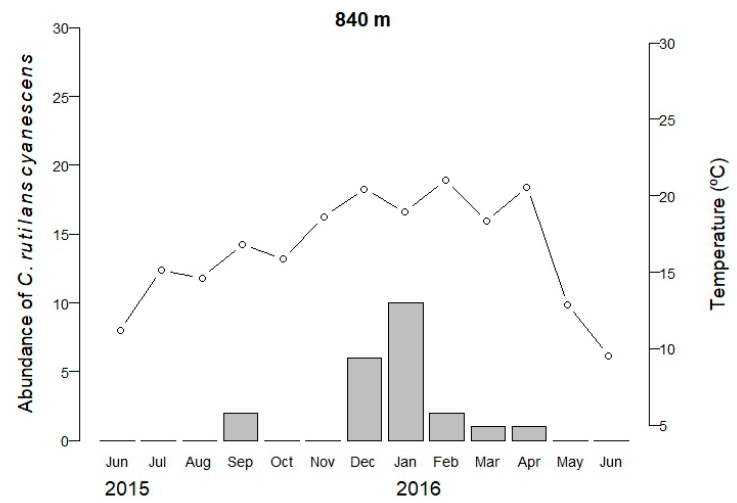

(C)

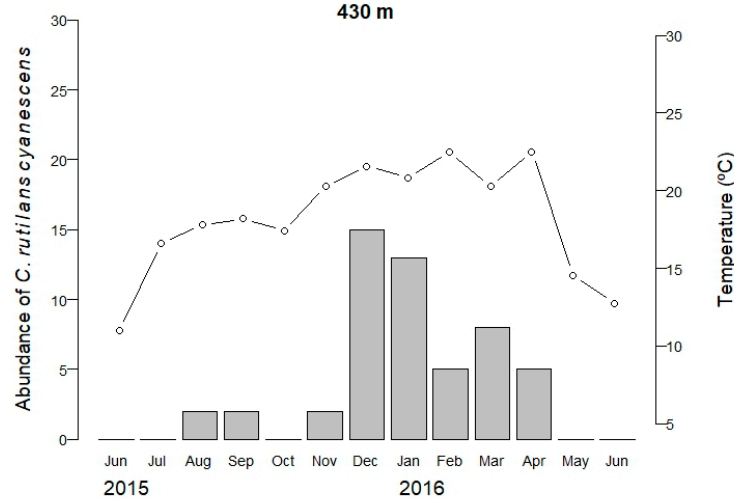

(B)

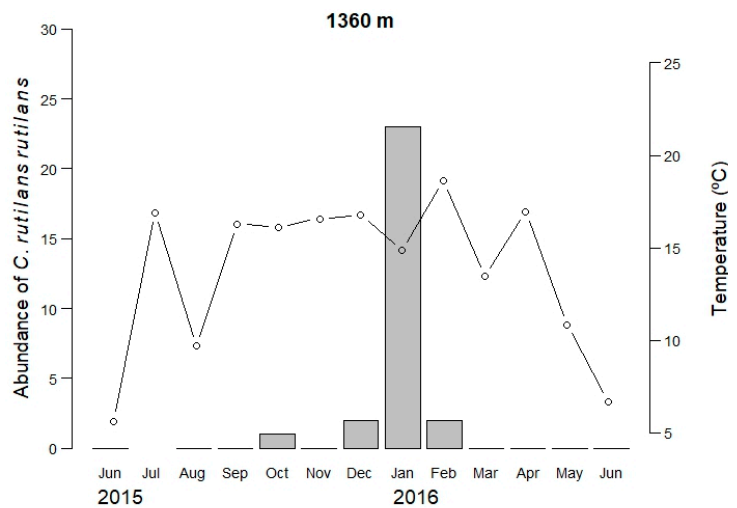

(D)

Figure 1. Spatial and temporal distribution of Canthon rutilans cyanescens at (A) $250 \mathrm{~m},($ B) $430 \mathrm{~m}$, and (C) $840 \mathrm{~m}$; and Canthon rutilans rutilans at (D) at $1360 \mathrm{~m}$, taking into account the number of collected individuals (bars), and variation in mean air temperature (circles) during each of the $48 \mathrm{~h}$ surveys.

\subsection{The Explanatory Capacity of Temperature}

A quadratic function of temperature (curvilinear) was able to account for $59.9 \%$ of total deviance in the presence-absence variation of $C$. rutilans cyanescens, while this explanatory capacity only reached $15.9 \%$ for C. rutilans rutilans. However, abundance variation at the sites with positive occurrences shows a linear and positive relationship with air temperature, accounting for $23.7 \%$ and $20.5 \%$ of the total variability, respectively.

\subsection{Derived Thermal Responses}

The air temperature of the sampling units at which both taxa were recorded oscillates from $15.3^{\circ} \mathrm{C}$ to $24.0^{\circ} \mathrm{C}$ in the case of $\mathrm{C}$. rutilans cyanescens, and from $14.4^{\circ} \mathrm{C}$ to $18.6^{\circ} \mathrm{C}$ for $\mathrm{C}$. rutilans rutilans (Figure 2). This overlap across the thermal gradient, when thermal limits derived from samples are considered, is significantly less pronounced if relative abundance frequencies are considered (Figure 2). In this case, only $5.6 \%$ of the area under the response curves would correspond to the overlapped thermal range. The maximum abundance of $C$. rutilans rutilans would appear at air temperatures from $14{ }^{\circ} \mathrm{C}$ to $16^{\circ} \mathrm{C}$, while $\mathrm{C}$. rutilans cyanescens would prefer higher temperatures (at least equal to or greater than $20^{\circ} \mathrm{C}$ ) even higher than those experienced in the studied sites. Data on the presence of adults at different temperatures can be seen in Table 1 (absence data were omitted from the table, but not from the analyses). 


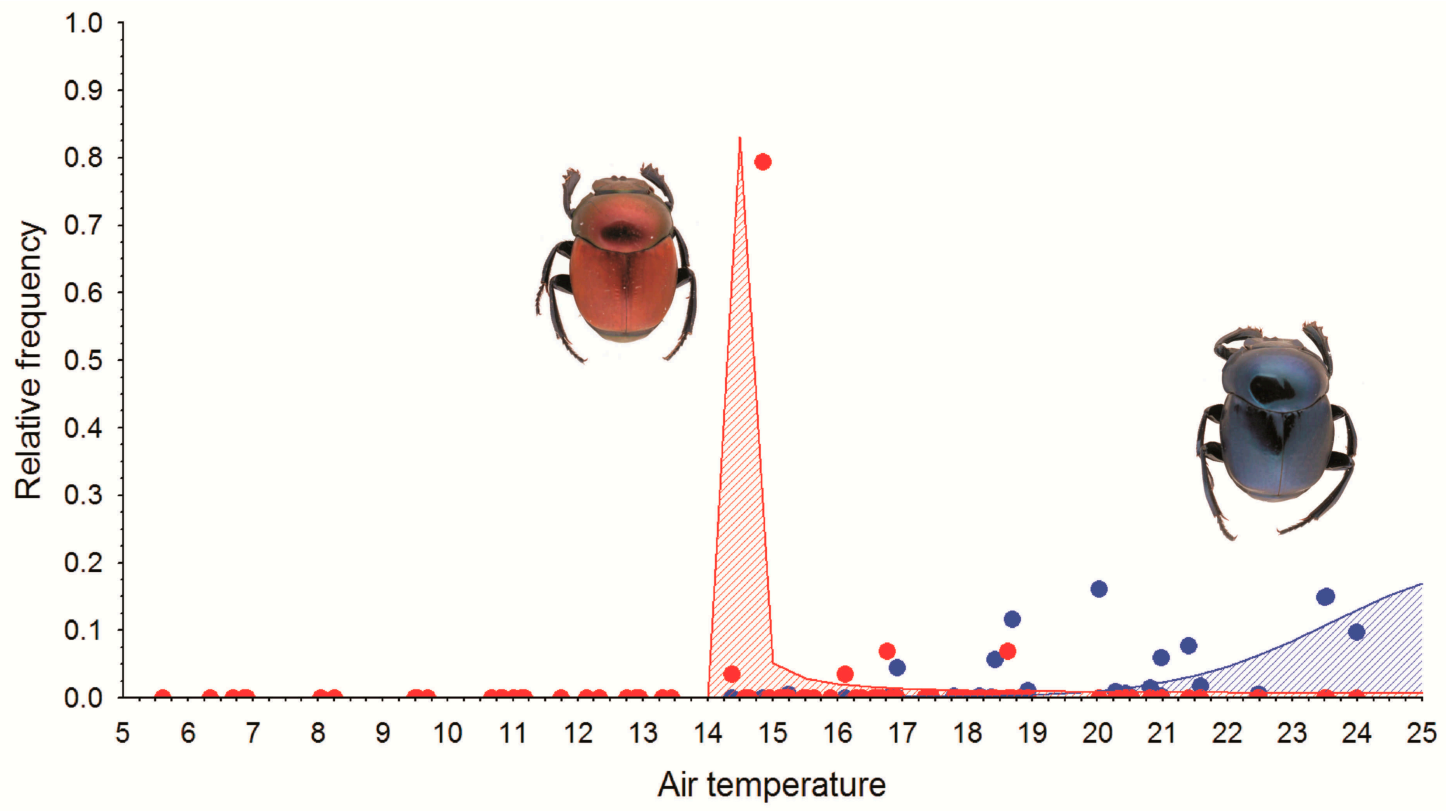

Figure 2. Temperature response curves for C. rutilans rutilans (in red) and C. rutilans cyanescens (in blue) considering the relative abundance of each sampling unit and its associated mean air temperature values $\left({ }^{\circ} \mathrm{C}\right)$. Points are observed values and lines represent adjusted curves.

Table 1. Presence of Canthon rutilans cyanescens and Canthon rutilans rutilans adults during the sampled year (June 2015 at June 2016). Mean temperature and mean minimum temperature $\left({ }^{\circ} \mathrm{C}\right)$ during the three days of sampling and also minimum temperature during the month.

\begin{tabular}{|c|c|c|c|c|c|}
\hline Subspecies & Area & Data & $\begin{array}{l}\text { Mean Temperature } \\
\left({ }^{\circ} \mathrm{C}\right)(3 \mathrm{~d})\end{array}$ & $\begin{array}{c}\text { Mean Minimum } \\
\text { Temperature }\left({ }^{\circ} \mathrm{C}\right)(3 \mathrm{~d})\end{array}$ & $\begin{array}{c}\text { Minimum Temperature } \\
\left({ }^{\circ} \mathrm{C}\right) \text { (Month) }\end{array}$ \\
\hline Canthon rutilans cyanescens & $250 \mathrm{~m}$ & $\mathrm{VII} / 2015$ & 16.91 & 15.47 & 6.67 \\
\hline Canthon rutilans cyanescens & $250 \mathrm{~m}$ & IX/2015 & 18.69 & 14.86 & 6.98 \\
\hline Canthon rutilans cyanescens & $250 \mathrm{~m}$ & $X / 2015$ & 18.42 & 15.85 & 10.26 \\
\hline Canthon rutilans cyanescens & $250 \mathrm{~m}$ & XI/2015 & 21.40 & 18.62 & 12.98 \\
\hline Canthon rutilans cyanescens & $250 \mathrm{~m}$ & $\mathrm{XII} / 2015$ & 23.54 & 19.76 & 15.57 \\
\hline Canthon rutilans cyanescens & $250 \mathrm{~m}$ & $\mathrm{II} / 2016$ & 24.00 & 20.49 & 14.80 \\
\hline Canthon rutilans cyanescens & $250 \mathrm{~m}$ & III/2016 & 20.03 & 17.70 & 14.71 \\
\hline Canthon rutilans cyanescens & $250 \mathrm{~m}$ & $\mathrm{IV} / 2016$ & 23.50 & 20.52 & 5.84 \\
\hline Canthon rutilans cyanescens & $250 \mathrm{~m}$ & V/2016 & 15.25 & 13.36 & 7.06 \\
\hline Canthon rutilans cyanescens & $430 \mathrm{~m}$ & VIII/2015 & 17.79 & 13.64 & 6.06 \\
\hline Canthon rutilans cyanescens & $430 \mathrm{~m}$ & IX/2015 & 18.19 & 15.56 & 6.06 \\
\hline Canthon rutilans cyanescens & $430 \mathrm{~m}$ & III/ 2016 & 20.29 & 17.57 & 14.13 \\
\hline Canthon rutilans cyanescens & $430 \mathrm{~m}$ & IV $/ 2016$ & 22.48 & 20.42 & 5.76 \\
\hline Canthon rutilans cyanescens & $840 \mathrm{~m}$ & IX/2015 & 16.82 & 14.38 & 2.20 \\
\hline Canthon rutilans cyanescens & $840 \mathrm{~m}$ & XII/2015 & 20.44 & 17.47 & 12.88 \\
\hline Canthon rutilans cyanescens & $840 \mathrm{~m}$ & $\mathrm{I} / 2016$ & 18.93 & 14.80 & 13.17 \\
\hline Canthon rutilans cyanescens & $840 \mathrm{~m}$ & $\mathrm{II} / 2016$ & 20.99 & 18.65 & 13.17 \\
\hline Canthon rutilans cyanescens & $840 \mathrm{~m}$ & $\mathrm{III} / 2016$ & 18.36 & 14.99 & 12.01 \\
\hline Canthon rutilans cyanescens & $840 \mathrm{~m}$ & IV / 2016 & 20.53 & 18.14 & 3.89 \\
\hline Canthon rutilans rutilans & $1360 \mathrm{~m}$ & $X / 2015$ & 16.12 & 12.82 & 2.73 \\
\hline Canthon rutilans rutilans & $1360 \mathrm{~m}$ & XII/2015 & 16.77 & 13.46 & 6.67 \\
\hline Canthon rutilans rutilans & $1360 \mathrm{~m}$ & $\mathrm{I} / 2016$ & 14.85 & 8.81 & 7.18 \\
\hline Canthon rutilans rutilans & $1360 \mathrm{~m}$ & $\mathrm{II} / 2016$ & 18.62 & 12.91 & 4.83 \\
\hline
\end{tabular}

\section{Discussion}

The obtained results indicate that C. rutilans cyanescens and C. rutilans rutilans do not overlap spatio-temporally as suggested by previously published faunistic and ecological studies [23,31-39]. 
Some examples of speciation through habitat isolation $[1,3,45,46]$ show that the previous isolation is followed by a subsequent adaption to the specific environmental conditions of each occurrence area [5]. Consequently, it is difficult to distinguish the ecological or geographical nature of this possible speciation process.

The different explanatory capacity of temperature on presence-absence data in both subspecies shows a higher dependence of Canthon rutilans cyanescens (59.9\%) adults to temperature than C. rutilans rutilans $(15.9 \%)$. C. rutilans cyanescens occurs in rainforest habitats with high temperatures and lower elevations, while C. rutilans rutilans lives at higher elevations and lower temperatures. Dung beetle species adapted to low temperatures generally have a shorter time to complete their reproductive activity. Therefore, they copulate and search for food to nest during a short period of time, mainly in the summer, possibly as an adaptation to cold environments [47]. In our study, there were months during the year (Figure 1) where the mean temperature could allow the activity of Canthon rutilans rutilans adults, however, they were absent. This could be because the life cycle only allows adult emergence when summer conditions arrive. After this short period of adult reproductive activity (winged phase), adults may go into hibernation during cold periods or perhaps go into a diapause phase in larvae or egg stages. All these possible adaptations would lead to a long life cycle waiting for a favorable period of time.

\section{Conclusions}

The spatio-temporal segregation of C. rutilans is associated with a differential capacity of environmental temperature that explains the occurrence of these two subspecies, especially with a limited overlap in their thermal response curves. These data suggest that each subspecies would also inhabit relatively different temperature conditions. Changes in the climatic conditions along an elevational gradient can become a barrier to dispersal, which facilitates allopatric speciation but also promotes changes in species richness and compositional patterns [48-50]. Considering that a thermal barrier may reflect the range of thermal conditions at which an organism can have a net positive demographic growth rate [51], the available results suggest that C. rutilans rutilans and C. rutilans cyanescens could be considered two different species with different physiological and ecological requirements. Thus, temperature-mediated divergent adaptation could well have generated the appearance of these subspecies, as seems to have happened in other groups [9].

The process that could have caused separation in the two different species can be attributed to vertical colonization, in which species living in low and warm regions expand their distribution to higher and cooler regions, adapting to lower temperatures [52,53]. According to Sobel and collaborators [5], the problem posed by ecogeographic isolation is that a difference in the niche of two taxa only shows that they are found in places with different environmental conditions, but this does not guarantee that there actually are genetic differences. Additional molecular, morphological and thermal physiological studies under controlled laboratory conditions would be necessary to corroborate the probable species status of these two taxa.

Author Contributions: Conceptualization, M.C.H., M.I.M.H. and J.M.L.; Methodology, M.C.H., M.I.M.H., P.G.d.S., V.A. and J.M.L.; Formal analysis, M.C.H. and J.M.L.; Investigation, M.C.H., M.I.M.H., P.G.d.S., V.A. and J.M.L.; Data curation, M.I.M.H.; Writing-review \& editing, M.C.H., M.I.M.H., P.G.d.S. and J.M.L.; Supervision, J.M.L. and M.I.M.H.; Project administration, M.I.M.H.; Funding acquisition, M.I.M.H.

Funding: This research was funded by Ciências Sem Fronteiras program of the Ministério da Educação via Coordenação de Aperfeiçoamento de Pessoal de Nível Superior-CAPES (88881.068089/2014-01).

Acknowledgments: We would like to thank the Parque Estadual da Serra do Tabuleiro, Reserva Particular do Patrimônio Natural Reserva Leão da Montanha, Plaza Caldas da Imperatriz Resort \& SPA and Fernando Brüggemann for logistical support and permission to access areas, as well as Instituto Chico Mendes de Conservação da Biodiversidade (Ministério do Meio Ambiente, Brazil) for permission to collect specimens. Furthermore, we would like to thank Diogo Roesner, Eloisa Alves, Victor Michelon, Renata Campos and Susana Méndez from Laboratório de Ecologia Terrestre Animal (UFSC) and Javier Carpintero who helped us during fieldwork. We thank CAPES for the scholarship awarded to $\mathrm{MCH}$ and $\mathrm{CNPq}$ for the productivity grant (Process: 307437/2017-5P) to M.I.M.H. 
Conflicts of Interest: The authors declare no conflicts of interest.

\section{References}

1. Ramsey, J.; Bradshaw, H.D.; Schemske, D.W. Components of reproductive isolation between the monkeyflowers Mimulus lewisii and M. cardinalis (Phrymaceae). Evolution 2003, 57, 1520-1534. [CrossRef] [PubMed]

2. Doebeli, M.; Dieckmann, U. Speciation along environmental gradients. Nature 2003, 421, 259-264. [CrossRef] [PubMed]

3. Angert, A.L.; Schemske, D.W. The evolution of species' distributions: Reciprocal transplants across the elevation ranges of Mimulus cardinalis and M. lewisii. Evolution 2005, 59, 1671-1684. [CrossRef] [PubMed]

4. Zink, R.M. The geography of speciation: Case studies from birds. Evolution 2012, 5, 541-546. [CrossRef]

5. Sobel, J.M.; Chen, G.F.; Watt, L.R.; Schemske, D.W. The biology of speciation. Evolution 2010, 64, $295-315$. [CrossRef] [PubMed]

6. Rahbek, C. The elevational gradient of species richness: A uniform pattern? Ecography 1995, 18, $200-205$. [CrossRef]

7. Lomolino, M.V. Elevation gradients of species-density historical and prospective views. Glob. Ecol. Biogeogr. 2001, 10, 3-13. [CrossRef]

8. Chen, I.C.; Shiu, H.J.; Benedick, S.; Holloway, J.D.; Cheye, V.K.; Barlow, H.S.; Hill, J.K.; Thomas, C.D. Elevation increases in moth assemblages over 42 years on a tropical mountain. Proc. Natl. Acad. Sci. USA 2009, 106, 1479-1483. [CrossRef] [PubMed]

9. Keller, I.; Seehausen, O. Thermal adaptation and ecological speciation. Mol. Ecol. 2012, 21, 782-799. [CrossRef] [PubMed]

10. Svensson, E.I. Non-ecological speciation, niche conservatism and thermal adaptation: How are they connected? Org. Divers. Evol. 2012, 12, 229-240. [CrossRef]

11. Phillimore, A.B.; Owens, I.P. Are subspecies useful in evolutionary and conservation biology? Proc. Biol. Sci. 2006, 273, 1049-1053. [CrossRef] [PubMed]

12. De Queiroz, K. Ernst Mayr and the modern concept of species. Proc. Natl. Acad. Sci. USA 2005, 102, 6600-6607. [CrossRef] [PubMed]

13. Chown, S.L.; Nicholson, S.W. Insect Physiological Ecology: Mechanisms and Patterns; Oxford University Press: Oxford, UK, 2004.

14. Vaz-de-Mello, F.; Larsen, T.; Silva, F.; Gill, B.; Spector, S.; Favila, M. The IUCN Red List of Threatened Species. Canthon rutilans, 2014. Available online: http:/ / www.iucnredlist.org/details/137210/0 (accessed on 20 September 2018).

15. Köppen, W. Das geographische System der Klimate. In Handbuch der Klimatologie, Gebrüder Borntraeger; Köppen, W., Geiger, R., Eds.; Gerbrüder Bornträger: Berlin, Germany, 1936; pp. 1-44.

16. Halffter, G.; Edmonds, W.D. The Nesting Behavior of Dung Beetles (Scarabaeinae). An Ecological and Evolutive Approach; Instituto de Ecología: Mexico City, Mexico, 1982; pp. 1-176.

17. Halffter, G.; Matthews, E.G. The natural history of dung beetles of the subfamily Scarabaeinae (Coleoptera, Scarabaeidae). Folia Entomol. Mex. 1966, 12-14, 1-312.

18. Nichols, E.; Spector, S.; Louzada, J.; Larsen, T.; Amezquita, S.; Favila, M.E. Ecological functions and ecosystem services provided by Scarabaeinae dung beetles. Biol. Conserv. 2008, 141, 1461-1474. [CrossRef]

19. Davis, A.L.; Brink, D.J.; Scholtz, C.H.; Prinsloo, L.C.; Deschodt, C.M. Functional implications of temperature-correlated colour polymorphism in an iridescent, scarabaeine dung beetle. Ecol. Entomol. 2008, 33, 771-779. [CrossRef]

20. Alves, V.M.; Hernández, M.I.M.; Lobo, J.M. Elytra absorb ultraviolet radiation but transmit infrared radiation in Neotropical Canthon species (Coleoptera, Scarabaeinae). Photochem. Photobiol. 2018, 94, 532-539. [CrossRef] [PubMed]

21. Hernández, M.I.M. The night and day of dung beetles (Coleoptera, Scarabaeidae) in the Serra do Japi, Brazil: Elytra colour related to daily activity. Rev. Bras. Entomol. 2002, 46, 597-600. [CrossRef]

22. Amore, V.; Hernández, M.I.M.; Carrascal, L.M.; Lobo, J.M. Exoskeleton may influence the internal body temperatures of Neotropical dung beetles (Col. Scarabaeinae). PeerJ 2017, 5, e3349. [CrossRef] [PubMed] 
23. Korasaki, V.; Lopes, J.; Gardner Brown, G.; Louzada, J. Using dung beetles to evaluate the effects of urbanization on Atlantic Forest biodiversity. Insect Sci. 2013, 20, 393-406. [CrossRef] [PubMed]

24. Culot, L.; Bovy, E.; Vaz-de-Mello, F.Z.; Guevara, R.; Galetti, M. Selective defaunation affects dung beetle communities in continuous Atlantic rainforest. Biol. Conserv. 2013, 163, 79-89. [CrossRef]

25. Bett, J.Z.; de Farias, P.M.; da Silva, P.G.; Hernández, M.I.M. Dung beetle communities in coal mining areas in the process of recovery. Biotemas 2014, 27, 197-200.

26. Da Silva, P.G.; Garcia, M.A.R.; Vidal, M.B. Besouros copro-necrófagos (Coleoptera: Scarabaeidae stricto sensu) coletados em ecótono natural de campo e mata em Bagé, RS. Ciênc. Nat. 2008, 30, 71-91.

27. Da Silva, P.G.; Audino, L.D.; Nogueira, J.M.; Moraes, L.P.; Vaz-de-Mello, F.Z. Escarabeíneos (Coleoptera: Scarabaeidae: Scarabaeinae) de uma área de campo nativo no bioma Pampa, Rio Grande do Sul, Brasil. Biota Neotrop. 2012, 12, 246-253. [CrossRef]

28. Da Silva, P.G. Dung beetles (Coleoptera, Scarabaeinae) from high-altitude grasslands in São Joaquim National Park, Santa Catarina, southern Brazil. Check List 2017, 13, 817-830. [CrossRef]

29. Audino, L.D.; da Silva, P.G.; Nogueira, J.M.; Moraes, L.P.; Vaz-de-Mello, F.Z. Scarabaeinae (Coleoptera, Scarabaeidae) de um bosque de eucalipto introduzido em uma região originalmente campestre. Iheringia Sér. Zool. 2011, 101, 121-126. [CrossRef]

30. Garcia, L.E.; Moraes, R.M.; Vianna, É.E.S. Levantamento de besouros copro-necrófagos (Coleoptera: Scarabaeidae: Scarabaeinae) do Bioma Pampa. Rev. Ciênc. Agrovet. 2016, 15, 144-154. [CrossRef]

31. Campos, R.C.; Hernández, M.I.M. Dung beetle assemblages (Coleoptera, Scarabaeinae) in Atlantic forest fragments in southern Brazil. Rev. Bras. Entomol. 2013, 57, 47-54. [CrossRef]

32. Campos, R.C.; Hernández, M.I.M. Changes in the dynamics of functional groups in communities of dung beetles in Atlantic forest fragments adjacent to transgenic maize crops. Ecol. Indic. 2015, 49, $216-227$. [CrossRef]

33. Campos, R.C.; Hernández, M.I.M. The importance of maize management on dung beetle communities in Atlantic Forest fragments. PLoS ONE 2015, 10, e0145000. [CrossRef] [PubMed]

34. Bogoni, J.A.; Hernández, M.I.M. Attractiveness of native mammal's feces of different trophic guilds to dung beetles (Coleoptera: Scarabaeinae). J. Insect Sci. 2014, 14, 299. [CrossRef] [PubMed]

35. Costa-Silva, V.; Cipolatto, R.P.; Abegg, A.D.; Rosa, C.M.; da Silva, P.G.; Di Mare, R.A. Escarabeídeos (Coleoptera: Scarabaeidae) de campo e floresta da Reserva Biológica de São Donato, Rio Grande do Sul, Brasil. Biotemas 2014, 27, 63-71. [CrossRef]

36. Da Silva, P.G.; Hernández, M.I.M. Local and regional effects on community structure of dung beetles in a mainland-island scenario. PLoS ONE 2014, 9, e111883. [CrossRef] [PubMed]

37. Da Silva, P.G.; Hernández, M.I.M. Scale-dependence of processes structuring dung beetle metacommunities using functional diversity and community deconstruction approaches. PLoS ONE 2015, 10, e0123030. [CrossRef] [PubMed]

38. Da Silva, P.G.; Hernández, M.I.M. Spatial patterns of movement of dung beetle species in a tropical forest suggest a new trap spacing for dung beetle biodiversity studies. PLoS ONE 2015, 10, e0126112. [CrossRef] [PubMed]

39. Da Silva, P.G.; Hernández, M.I.M. Spatial variation of dung beetle assemblages associated with forest structure in remnants of southern Brazilian Atlantic Forest. Rev. Bras. Entomol. 2016, 60, 73-81. [CrossRef]

40. Da Silva, P.G.; Garcia, M.A.R.; Vidal, M.B. Besouros copro-necrófagos (Coleoptera: Scarabaeidae sensu stricto) do município de Bagé, RS (Bioma Campos Sulinos). Biociências 2009, 17, $33-43$.

41. Hernández, M.I.M.; Vaz-de-Mello, F.Z. Seasonal and spatial species richness variation of dung beetle (Coleoptera, Scarabaeidae s. str.) in the Atlantic Forest of southeastern Brazil. Rev. Bras. Entomol. 2009, 53, 607-613. [CrossRef]

42. Wiens, J.J.; Graham, C.H. Niche Conservatism: Integrating Evolution, Ecology, and Conservation Biology. Annu. Rev. Ecol. Evol. Syst. 2005, 36, 519-539. [CrossRef]

43. IBGE. Manual Técnico da Vegetação Brasileira; Instituto Brasileiro de Geografia e Estatística: Rio de Janeiro, Brazil, 1992.

44. Dobson, A. An Introduction to Generalized Linear Models; Chapman and Hall/CRC: Boca Raton, FL, USA, 1999.

45. Matute, D.R.; Novak, C.J.; Coyne, J.A. Temperature-based extrinsic reproductive isolation in two species of Drosophila. Evolution 2009, 63, 595-612. [CrossRef] [PubMed] 
46. Fuller, R.C.; McGhee, K.E.; Schrader, M. Speciation in killifish and the role of salt tolerance. J. Evol. Biol. 2007, 20, 1962-1975. [CrossRef] [PubMed]

47. Lumaret, J.P.; Stiernet, N. Montane Dung Beetles. In Dung Beetle Ecology; Hanski, I., Cambefort, Y., Eds.; Princeton University Press: Princeton, NJ, USA, 1991; pp. 242-254.

48. Janzen, D.H. Why mountain passes are higher in the tropics. Am. Nat. 1967, 101, 233-249. [CrossRef]

49. Ghalambor, C.K.; Huey, R.B.; Martin, P.R.; Tewksbury, J.J.; Wang, G. Are mountain passes higher in the tropics? Janzen's hypothesis revisited. Integr. Comp. Biol. 2006, 46, 5-17. [CrossRef] [PubMed]

50. Mittelbach, G.G.; Schemske, D.W.; Cornell, H.V.; Allen, A.P.; Brown, J.M.; Bush, M.B.; Harrison, S.P.; Hurlbert, A.H.; Knowlton, N.; Lessios, H.A.; et al. Evolution and the latitudinal diversity gradient: Speciation, extinction and biogeography. Ecol. Lett. 2007, 10, 315-331. [CrossRef] [PubMed]

51. Sunday, J.M.; Bates, A.E.; Kearney, M.R.; Colwell, R.K.; Dulvy, N.K.; Longino, J.T.; Huey, R.B. Thermal-safety margins and the necessity of thermoregulatory behavior across latitude and elevation. Proc. Natl. Acad. Sci. USA 2014, 111, 5610-5615. [CrossRef] [PubMed]

52. Lobo, J.M.; Halffter, G. Biogeographical and ecological factors affecting the altitudinal variation of mountainous communities of coprophagous beetles (Coleoptera: Scarabaeoidea): A comparative study. Ann. Entomol. Soc. Am. 2014, 93, 115-126. [CrossRef]

53. Da Silva, P.G.; Lobo, J.M.; Hensen, M.C.; Vaz-de-Mello, F.Z.; Hernández, M.I.M. Turnover and nestedness in subtropical dung beetle assemblages along an elevational gradient. Divers. Distrib. 2018, 24, 1277-1290. [CrossRef]

(C) 2018 by the authors. Licensee MDPI, Basel, Switzerland. This article is an open access article distributed under the terms and conditions of the Creative Commons Attribution (CC BY) license (http:/ / creativecommons.org/licenses/by/4.0/). 